ANDRZEJ CZYŻEWSKI

MARYLA BIENIEK-MAJKA

DARIUSZ CZAKOWSKI

\title{
Factors shaping supply- demand relations on the fruit and vegetable market in the light of the behavior of groups and producer organizations
}

Prof. Andrzej Czyżewski, Full Professor Poznan University of Economics Head of Department of Macro and Agricultural Economics

Maryla Bieniek-Majka, Ph. D. Kujawy and Pomorze University in Bydgoszcz

Dariusz Czakowski, Ph. D. Kujawy and Pomorze University in Bydgoszcz

\section{Introduction}

The fruit and vegetable market in Poland is covered by the regulations of the Common Market Organization of Fruit and Vegetables, which was established in 1996 in the European Union. These provisions regulate issues related to with the quality of goods put into circulation and protection of the internal market (Kapusta 2014, pp. 9-10). Regulations regarding financial support were a key aspect for producers. In 2007, the European Commission decided to increase the co-financing level for groups and organizations of fruit and vegetable producers. The reform, which came into force on January 1, 2008, mobilized many small farms to group themselves into groups and producer organizations (Filipiak 2014, pp. 2426). The effect of the consolidation process on the fruit and vegetable market was to increase interest in the construction or modernization of infrastructure allowing to store and prepare a larger amount of raw materials for sale. The main purpose of this article is to determine the interdependencies between the developments 
on the fruit and vegetable market in Poland, and the functioning and integration processes of producer groups and organizations in this sector.

\section{Research Methodology}

On the basis of literature studies and secondary data published by the Central Statistical Office and made available by the Ministry of Agriculture and Rural Development and the Agency for Restructuring and Modernization of Agriculture, the prices on the fruit and vegetable market, the size of the area dedicated to their cultivation and its effectiveness are presented. The results were presented in tabular and graphical form. Using the basic statistical methods, changes in the structure and share of the area for cultivation of fruit and vegetables by integrated producers and the value of sales obtained by them were presented. Pearson's correlation showed the extent to which market factors correlated with the number of groups and organizations of fruit and vegetable producers, the area allocated to them for horticultural crops and the value of sales obtained by them.

\section{Demand-supply relations on the fruit and vegetable market in Poland}

One of the incentives for integration in the fruit and vegetable market was the creation of a better negotiating position when cooperating with recipients, which were increasingly becoming retail chains (Bieniek-Majka 2013, pp. 171180). The accession to the European Union resulted in Poland's accession to the Single European Market, which significantly influenced the domestic prices of fruit and vegetables. The abolition of trade barriers between Poland and the EU countries led to the harmonization of the price level between the domestic and EU agricultural market, and guaranteed greater stabilization. It also determined the relationship with price changes on the world market (Czakowski, Czyżewski 2017, pp. 136-145).

Prices of fruit and vegetables are subject to seasonal fluctuations, mainly due to unfavorable agrometeorological conditions that contribute to crop failure. Growing fruit is particularly sensitive to bad weather. In the analyzed period, this was evidenced by the coefficient of fruit price volatility, which was at the level of $22.3 \%$, while for vegetable prices it amounted to $13.1 \%$. Similar conclusions can be drawn following the evolution of the cumulative inflation dynamics and the purchase prices of fruit and vegetables (figure 1). The amplitude of vegetable prices was clearly smaller than fruit. The most rapid price increases took place

Factors shaping supply-demand relations

on the fruit and vegetable market in the light of the behavior of groups and producer 


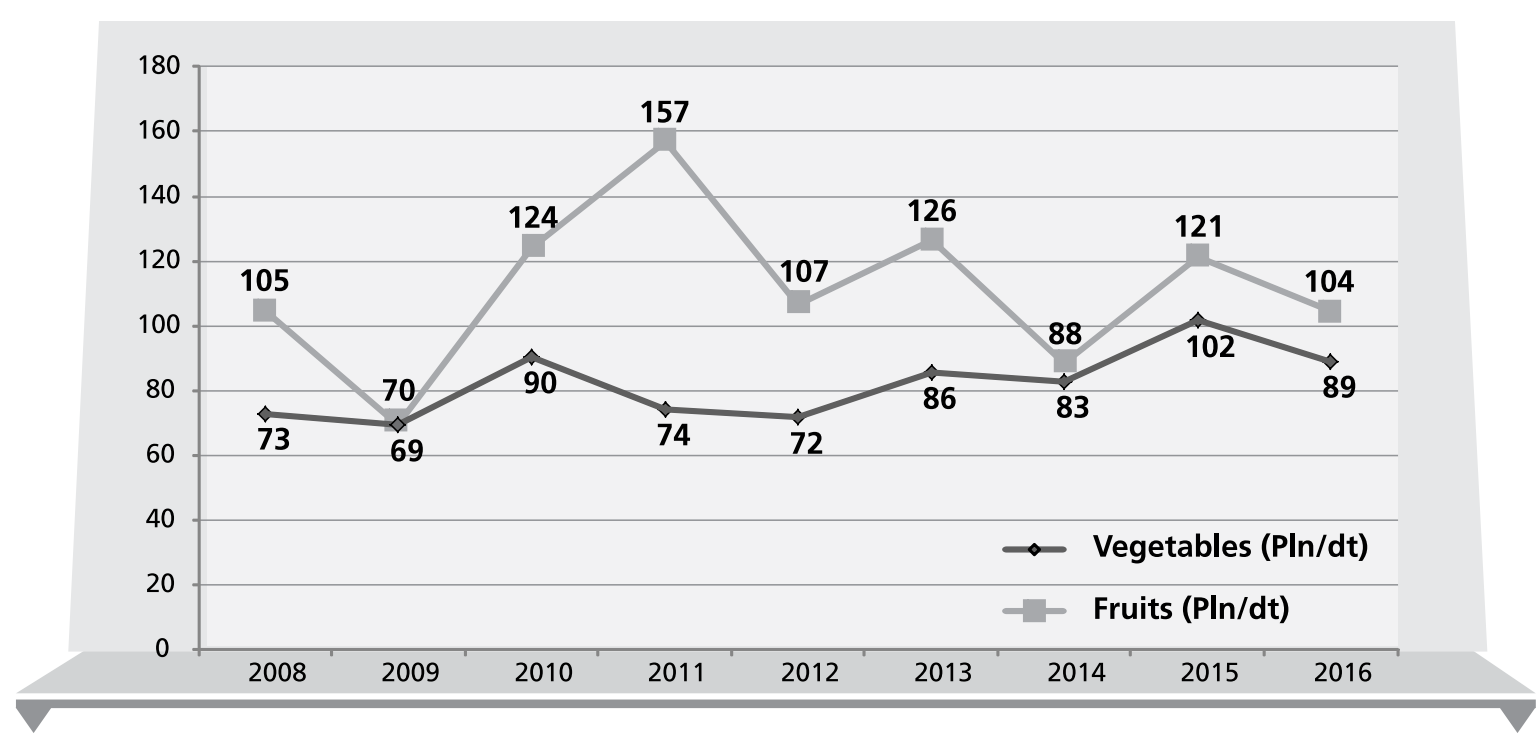

Figure 1. Average annual real purchase prices of fruit and vegetables in Poland in 2008-2016 (fixed prices according to weighted averages from 2016, in PLN / dt)

Source: : CSO, 2009-2017, Purchase and prices of agricultural products (data for 2008-2016), Warsaw

in 2010 as a result of losses in the collections caused by floods and in 2011, which was caused by the May frosts (GUS 2011). It is worth noting that the dynamics of fruit and vegetable prices was higher than the inflation rate, despite growing competition on the domestic and foreign markets (Nosecka, Pawlak, Poczta 2011, pp. 33-43, Czakowski 2017, pp. 161-180). It is worth adding that currently on the markets of agricultural products we observe the activity of the so-called technological treadmill. This mechanism forces farmers to constantly increase labor productivity leading to cost reduction, which in turn does not translate into an increase in income due to declining prices of agricultural commodities (Czakowski 2016, pp. 247-260). In addition, the immobility of land and the lumpiness of the assets invested in farms mean that farmers are unable to transfer their production factors to alternative uses (Czyżewski A., Czyżewski B. 2015, p. 32).

Fruit and vegetable production is an important branch of domestic agriculture. Despite the relatively small areas designated for their cultivation, the share in the value of agricultural commodity in 2016 was $8.4 \%$ for vegetables and $6.8 \%$ for fruits, and 15.2\% for total (GUS 2016). Data from 2008-2016 show a clear increase in the size of fruit harvest (table 1). It is worth noting that the average annual harvest of fruit from trees and nuts as well as berry fruits increased to a similar 
degree. Interestingly, the area under berry cultivation grew at a similar pace as the growth of their harvest. This indicates that the development of this type of fruit was extensive. On the other hand, the situation was different in the case of fruit from trees and orchards, where the area of orchards was at a similar level, and yet there was an increase in harvests, among others due to the fact that the increase in harvest was determined by the share of dwarf trees and the increase in apple crop areas (Czyżewski, Czakowski 2016, pp. 511-519).

\section{Table 1. Area of cultivation and size of harvest and purchase of individual fruits and vegetables in Poland in the years 2008-2016}

\begin{tabular}{|c|c|c|c|c|c|c|}
\hline & $\begin{array}{c}\text { Vegetable } \\
\text { area } \\
\text { (thousand } \\
\text { ha) }\end{array}$ & $\begin{array}{c}\text { Vegetable } \\
\text { harvest } \\
\text { (thousand } \\
\text { tonnes) }\end{array}$ & $\begin{array}{l}\text { Amount of pur- } \\
\text { chase of vegeta- } \\
\text { bles (thousand } \\
\text { tonnes) }\end{array}$ & $\begin{array}{c}\text { Fruit grow- } \\
\text { ing area } \\
\text { (thousand } \\
\text { ha) }\end{array}$ & $\begin{array}{c}\text { Fruit } \\
\text { harvest } \\
\text { (thousand } \\
\text { tons) }\end{array}$ & $\begin{array}{c}\text { The volume } \\
\text { of fruit } \\
\text { purchase } \\
\text { (thousand } \\
\text { tonnes) }\end{array}$ \\
\hline 2008 & 203,0 & 5202,8 & 1235,8 & 409 & 3840,9 & 1374,3 \\
\hline 2009 & 211,8 & 5600,6 & 1334,4 & 409,9 & 3646,2 & 2186,5 \\
\hline 2010 & 163,6 & 4877,9 & 1370,5 & 410,2 & 2743,5 & 1615,1 \\
\hline 2011 & 183,9 & 5575,2 & 1533,4 & 428,7 & 3414,6 & 1736,5 \\
\hline 2012 & 180,8 & 5430,5 & 1678,4 & 431,7 & 3843,2 & 2736,4 \\
\hline 2013 & 147,5 & 4986 & 1683,2 & 424,9 & 4129,5 & 2882,4 \\
\hline 2014 & 178,0 & 5607,2 & 1817,5 & 386,3 & 4188,9 & 2875,2 \\
\hline 2015 & 181,1 & 4795,1 & 1652 & 390,2 & 4048,9 & 2554,7 \\
\hline 2016 & 184,1 & 5610,2 & 1740,7 & 392,4 & 4643,7 & 2539,7 \\
\hline $\begin{array}{c}\text { Average for } \\
\text { the years } \\
2008-2016\end{array}$ & 181,53 & 5298,39 & 1560,66 & 409,26 & 3833,27 & 2277,87 \\
\hline $\begin{array}{c}\text { Dynamics } \\
\text { rate } 2016 / 2008 \\
(2008=100)\end{array}$ & 90,69 & 107,83 & 140,86 & 95,94 & 120,90 & 184,80 \\
\hline
\end{tabular}

Source: CSO, 2009 -2017, Purchase and prices of agricultural products (data for the years 2008 -2016), Warsaw; GUS, 2009 -2017, Plant production results (data for 2008 -2016), Warsaw 
In the analyzed period, a noticeable increase in the share of purchase in relation to the size of harvests, both fruit and vegetables can be noticed (table. 1). This process was determined, among others through changes taking place on the domestic market. First of all, the processes of concentration and specialization of products should be mentioned. The above changes were accompanied by an increase in the average area of farms (Ziętara, Sobierajewska 2012, pp. 2829). Thus, a small group of small producers delivering goods to the market in the form of direct sales decreased. The increase in the purchase of fruit and vegetables was also due to investments in this market, which allowed many producers to develop the warehouse base, thanks to which they could operate on a larger scale. Sales also emphasize the strong competitive position of the Polish fruit and vegetable sector, which translated into dynamically growing exports (Czyżewski, Czakowski 2016, pp. 511-519).

\section{Participation of groups and organization manufacturers in the fruit and vegetable market in Poland}

The development of the supply of fruit and vegetables was undoubtedly influenced by the possibility of using the Common Agricultural Policy instruments encouraging to organize the market that emerged after Poland's accession to the European Union. Motivated by the benefits of implementing the integration program, Polish manufacturers have intensively consolidated. The boom of newly established groups of fruit and vegetable producers fell in the years 2008-2012, a period in which the provisions guaranteeing a wide stream of funds to cover eligible investment costs within the framework of the implementation of the so-called an investigation plan for recognition ${ }^{1}$. Comparing the process of integration on the Polish fruit and vegetable market, legislative changes restricting access to financial resources reveal a very strong relationship (Bieniek-Majka 2014, p. 88) which confirms the belief that the

1 The recognition investigation plan covers a maximum period of 5 years. It is based on the newly formed groups of fruit and vegetable producers that aspire to be the producer organization. It contains, among others information about planned investments, planned value of production along with measures and actions taken to achieve intentions. It is drawn up on the basis of the Regulation of the Minister of Agriculture and Rural Development of 16 December 2008 on the conditions for pre-recognition of fruit and vegetable producer groups, recognition of fruit and vegetable producer organizations and conditions and requirements to be met by recognition plans (Journal of Laws from 2009 No. 5, item 27) and complies with the provisions of European Union regulations. 
possibility of using a "political rent" in the form of investment co-financing a catalyst for the integration process on the fruit and vegetable market in Poland. Limiting the amount of support (from 2012) resulted in the lack of interest in setting up new ones and removing existing units (Figure 2). The trend function shown is an estimate of the number of producer groups and organizations, where $x$ is a time variable that takes values 1-9. The approximation coefficient $R 2$ $=0.9669$ indicates a good approximation.

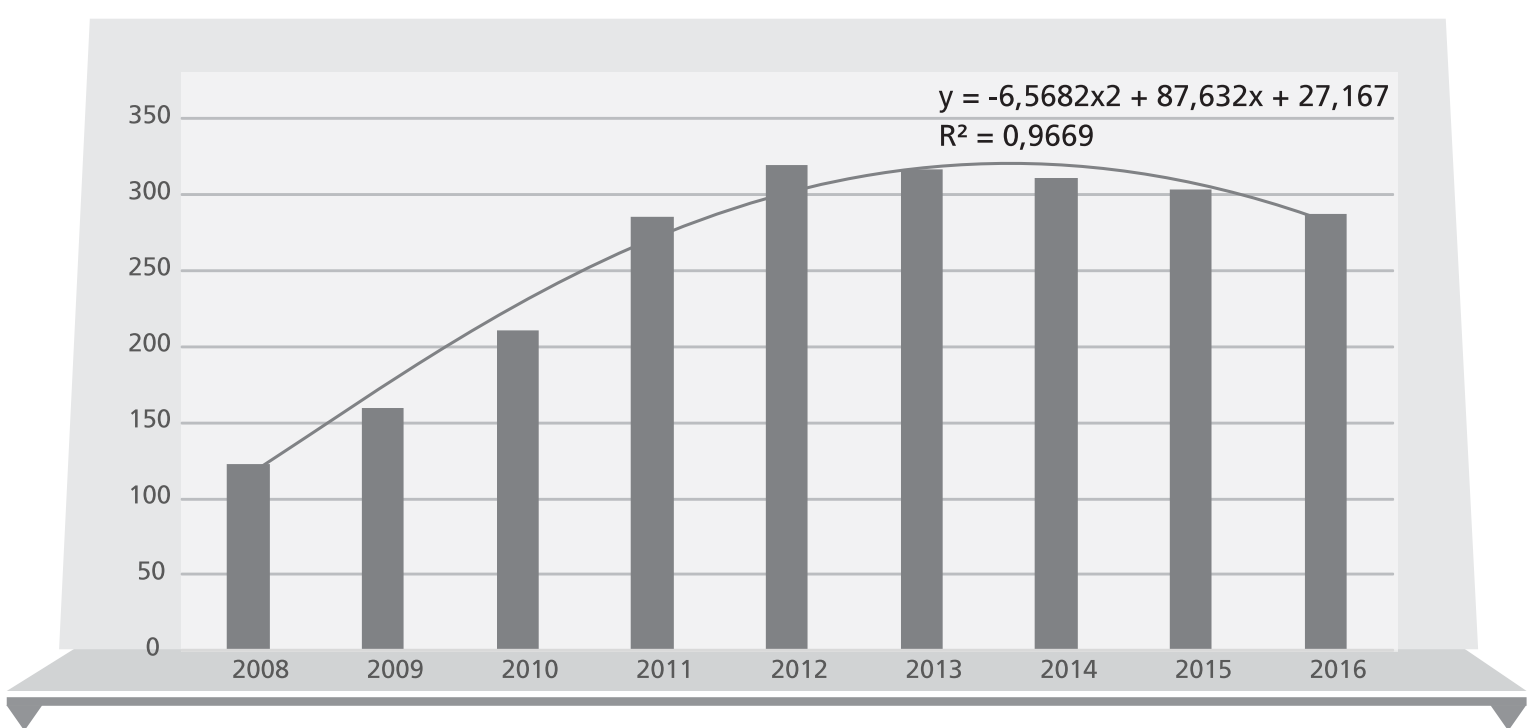

Figure 2. Number of groups and organizations of fruit and vegetable producers in Poland in 2008-2016

Source: : own study based on unpublished data provided by the Ministry of Agriculture and Rural Development, as well as the Agency for Restructuring and Modernization of Agriculture

The goal of the integration of producers was the concentration of supply and the possibility of guaranteeing large, homogeneous batches of goods that meet the increasingly higher requirements set by recipients, which, as mentioned earlier, more and more often became the market chains that are becoming more and more important on the market. The effectiveness of this idea can be demonstrated by the data contained in tab. 2. On this basis, we can conclude that the possibilities of interception of value added by producers have increased. Increasing the competitiveness and increase in revenues from the sale of products offered by groups and producer organizations to the market caused 
that by 2012 the number of producer groups and organizations growing, which allocated more and more land for horticultural cultivation.

When comparing the growth of the area allocated by integrated producers to the production of fruit and vegetables in relation to the increase in the value of production obtained from this activity, we see that the value of sold production in comparison to 2008 disproportionally increased until 2013. The share of land cultivated by members of fruit and vegetable producer groups and organizations increased by $241 \%$, and the share in the value of sold production by $768 \%$.

Unfortunately, after 2013, the share in the value of fruit and vegetable production sold by integrated producers decreased at the relatively maintained level of the area earmarked for their cultivation.

Table 2. Share of the area and value of fruit and vegetable production sold by fruit and vegetable producer groups and organizations in Poland in 2008-2016

\begin{tabular}{c|c|c|c|c}
\hline Year & $\begin{array}{c}\text { Share of the fruit and vegetable } \\
\text { production area of group mem- } \\
\text { bers and producer organiza- } \\
\text { tions in the total area dedicated } \\
\text { to the production of fruit and } \\
\text { vegetables }\end{array}$ & $\begin{array}{c}\text { Growth to } \\
\text { the base } \\
\text { year 2008 }\end{array}$ & $\begin{array}{c}\text { Share of the value sold by } \\
\text { members of groups and } \\
\text { organizations of fruit and } \\
\text { vegetable producers in } \\
\text { the total value of fruit and } \\
\text { vegetables sold }\end{array}$ & $\begin{array}{c}\text { Growth to } \\
\text { the base } \\
\text { year 2008 }\end{array}$ \\
\hline 2008 & 3,04 & $\times 100$ & 3,58 & $\times 100$ \\
\hline 2009 & 4,84 & 159,21 & 11,64 & 325,14 \\
\hline 2010 & 15,78 & 519,08 & 14,41 & 402,51 \\
\hline 2011 & 8,69 & 285,86 & 29,92 & 835,75 \\
\hline 2012 & 9,74 & 320,39 & 27,22 & 760,34 \\
\hline 2013 & 10,37 & 341,12 & 31,09 & 868,44 \\
\hline 2014 & 11,70 & 384,87 & 26,53 & 741,06 \\
\hline 2015 & 11,67 & 383,88 & 26,07 & 728,21 \\
\hline 2016 & 10,60 & 348,68 & 28,10 & 784,92 \\
\hline
\end{tabular}

Source: own study based on published data is not made available by the Ministry of Agriculture and Rural Development and the Agency for Restructuring and Modernization of Agriculture 
Despite the decreases in the share in the value of sales, we can conclude that from the beginning of the analyzed period, the market share of groups and organizations of fruit and vegetable producers has been strengthened. However, attention should be paid to the fact that the costly investment process, which was intense and despite considerable external support, negatively affected the profitability of sales. On the basis of detailed studies of the profitability of groups and organizations of fruit and vegetable producers from the KuyavianPomeranian Voivodeship ${ }^{2}$, which covered the years 2005-2014, it can be noticed that the growing value of sales did not keep up with the growth of costs generated by producer groups and organizations (inter alia related to external capital servicing), which meant that sales in 2009 and from 2011 did not it was profitable (Bieniek-Majka, Matuszczak 2017, pp. 7-16). The year 2010 was specific, in which the agrometeorological conditions (flood) affected the market causing price increase (figure 1). The increase in revenues directly affected the profitability of sales of the surveyed units.

Paying attention to the factors determining the functioning of groups and organizations of fruit and vegetable producers, one should emphasize the noticeable "specialization" in the production of vegetables. Considering the inability to specify the specifics of producer groups / organizations due to the fact that the majority of them flexibly made a choice by forming both fruit and vegetable categories. The obtained data allow this "specialization" to be identified. It has been confirmed, among others through a statistically significant relationship between the shaping of real vegetable procurement prices and the area of production and vegetables of group members and producer organizations. It can therefore be concluded that the development of real vegetable procurement prices had a greater impact on the decisions of group members and producer organizations regarding the production area, rather than the price volatility in the fruit market. At the same time, it was noted that with the declining area of vegetable growing in Poland, producers being members of groups increased the area dedicated to growing vegetables. This has been confirmed by a stronger relationship of the vegetable growing area than fruit with the area intended for cultivation vegetables in Poland, and the area intended for their cultivation by integrated producers (table 3 ).

2 Fruit and vegetable producers from the Kuyavian-Pomeranian Voivodeship were among the leaders in the team on this market. Sixth glass names for $13 \%$ of all groups and organizations of fruit and vegetable producers.

Factors shaping supply-demand relations on the fruit and vegetable market in the light of the behavior of groups and producer 
Table 3. Values of Pearson's linear correlation coefficients between the area of cultivation, the volume of commodity production, the price and volume of fruit and vegetables purchase, and the number of groups and organizations of fruit and vegetable producers, the area they are dedicated to and the value of their production sold in Poland in 2008-2016

\begin{tabular}{|c|c|c|}
\hline Explanation variable & Explanatory variable & 2008-2016 \\
\hline \multirow{4}{*}{$\begin{array}{l}\text { The area of fruit and } \\
\text { vegetable production } \\
\text { of group members and } \\
\text { producer organizations }\end{array}$} & Vegetable area & $-0,77^{\mathrm{a}}$ \\
\hline & Fruit growing area & $-0,14$ \\
\hline & The purchase price of vegetables & $0,72^{\mathrm{a}}$ \\
\hline & Price of fruit purchase & 0,46 \\
\hline \multirow{4}{*}{$\begin{array}{l}\text { Value sold by members } \\
\text { of fruit and vegetable } \\
\text { producer groups and } \\
\text { organizations }\end{array}$} & The volume of buying vegetables & $0,92^{\mathrm{a}}$ \\
\hline & The volume of fruit purchase & $0,72^{\mathrm{a}}$ \\
\hline & Commodity production of vegetables & $0,84^{\mathrm{a}}$ \\
\hline & Commodity production of fruit & $0,7^{\mathrm{a}}$ \\
\hline \multirow{4}{*}{$\begin{array}{l}\text { The number of fruit } \\
\text { and vegetable producer } \\
\text { groups and organiza- } \\
\text { tions }\end{array}$} & The volume of buying vegetables & $0,93^{\mathrm{a}}$ \\
\hline & The volume of fruit purchase & $0,78^{\mathrm{a}}$ \\
\hline & Commodity production of vegetables & $0,82^{\mathrm{a}}$ \\
\hline & Commodity production of fruit & 0,57 \\
\hline
\end{tabular}

${ }^{a}$ the correlation coefficient is statistically significant $(p=0.05$, for $n=9$, critical wile 0.6664$)$

Source: own calculations based on unpublished data made available by the Ministry of Agriculture and Rural Development, as well as the Agency for Restructuring and

Modernization of Agriculture and CSO, 2009 -2017, Purchase and prices of agricultural products (data for 2008 -2016), Warsaw; GUS, 2005-2017, Plant production results (data for the years 2008 -2016), Warsaw. Calculations using the econometric package Statistica ver. 12

In addition, research has shown a stronger link between the buying-in and commodity production of vegetables rather than fruit, and the overall sales value obtained by producer groups and organizations. Analogously to the number of registered producer groups and organizations, the volume of purchase and production of vegetables was stronger than fruit. The indicated dependencies are not surprising, because in the face of market difficulties (e.g. embargo, which most affected fruit producers, especially apples) it is easier to change the yield

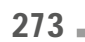


of vegetables than fruit. This is due to the fact that the production of vegetables is more flexible than fruit, for example due to the shorter time intended for cultivation, that is, from sowing / planting to harvesting.

However, despite reacting to market changes, it is a rise in supply, with decreasing domestic demand (Bieniek-Majka 2015a, p. 28), a closed (from August 2014) Russian market ${ }^{3}$, increasing costs, which translated into the profitability of groups and organizations of fruit and vegetable producers, caused some of them to cease their activities. As of 02.01.2018, according to the register (ARMA 2018) maintained by the President of ARMA, there were only 285 units operating, which is about $17 \%$ less compared to the total number of groups and organizations of fruit and vegetable producers registered at that time .

\section{Conclusion}

1. Over the period considered, the increase in the size of fruit and vegetable harvests was recorded despite the decrease in the area of land dedicated to these crops. Increasing production efficiency may have resulted, among others, from increasing the share of cultivated area by integrated fruit and vegetable producers. Their share in the total area grew and from 2013 it is at the level of $10-11 \%$. It is worth noting that the reduction of the area dedicated to the cultivation of fruit and declines in their prices from 2014 could be dictated by the introduction of embargo by the largest recipient of Polish gardening products (Bieniek-Majka 2015b, p. 34);

2. Significant support mechanisms under the Common Agricultural Policy allowed for integration processes on the fruit and vegetable market in Poland. This was confirmed by the increase in the share of fruit and vegetable group members and producer organizations in the total value of total fruit and vegetable sales in the first six years of research (2008-2013). Unfortunately, in the years 2014-2016 this share slightly decreased. It resulted, among others, from the simultaneous decline in the number of producer groups and organizations and the volatility of fruit and vegetable prices.

3. Based on correlation studies, it can be concluded that the functioning and the integration process of groups and organizations of fruit and vegetable producers (defined by the area under cultivation, the value sold and the number of integrated producers) more strongly affected the situation on the

3 The Russian market was the main recipient of Polish apples.

Factors shaping supply-demand relations

on the fruit and vegetable market in the light of the behavior of groups and producer 
vegetable market than fruit (measured by prices and volume of purchase, area of cultivation and production of goods).

4. Fruit and vegetable markets in the countries of the so-called "old" Union are very well developed and organized. Therefore, gardeners from Poland, in order to be competitive on the domestic and international market, should increase their market power, inter alia, through integration processes. Unfortunately, in Poland after 2013, instead of developing the organization of the fruit and vegetable market, we can see its contraction. This was helped, among others a prolonged embargo and a reduction in funding by the European Union. In the face of the above, it would be advisable to develop adequate instruments and support mechanisms for this sector, as it turns out that those operating so far (e.g. the program of compensation for the withdrawal of products from the market) seem to be insufficient.

\section{Summary}

Factors shaping supply-demand relations on the fruit and vegetable market in the light of the behavior of groups and producer organizations

The authors have addressed the question to what extent the functioning of groups and organizations of fruit and vegetable producers depends on the market situation, the authors presented the shaping of supply-demand relations on the fruit and vegetable market in Poland in 2008-2016. They drew attention to the decreasing area of land intended for horticultural crops, with the simultaneous increase in the size of supply. They presented changing productive structures and showed changes in the market share of fruit and vegetable producer groups and organizations. They noticed that the market situation (prices, demand, costs, embargo) caused that the number of fruit and vegetable producers' groups and organizations on the market decreased, which was reflected in the market situation.

Key words: fruit and vegetable market, integration, groups and organizations of fruit and vegetable producers.

\section{Streszczenie}

Wpływ uwarunkowań relacji popytowo-podażowych na rynku owoców i warzyw na zachowanie grup i organizacji producentów owoców i warzyw 
Autorzy podjęli problem, w jakim stopniu funkcjonowanie grup i organizacji producentów owoców i warzyw jest zależne od sytuacji rynkowej. Autorzy przedstawili kształtowanie się relacji popytowo-podażowych na rynku owoców i warzyw w Polsce w latach 2008-2016. Zwrócili uwagę na zmniejszający się areał ziemi przeznaczonej na uprawy ogrodnicze, przy jednoczesnym wzroście wielkości podaży. Przedstawili zmieniające się struktury wytwórcze oraz ukazali zmiany w udziale w rynku grup i organizacji producentów owoców i warzyw. Zauważyli, że sytuacja rynkowa (ceny, popyt, koszty, embargo) spowodowała, iż liczba funkcjonujących na rynku grup i organizacji producentów owoców i warzyw zmniejszyła się, co znalazło odzwierciedlenie w sytuacji rynkowej.

\section{Słowa}

kluczowe: rynek owoców i warzyw, integracja, grupy i organizacje producentów owoców i warzyw.

\section{JEL \\ Classification: Q11, Q13}

\section{References}

1. Agencja Restrukturyzacji i Modernizacji Rolnictwa - unpublished data.

2. Bieniek-Majka M. (2013), Wspótpraca z sieciami handlowymi jako dostosowanie się producentów owoców i warzyw do wymagań wspótczesnego rynku, „Roczniki Ekonomiczne Kujawsko-Pomorskiej Szkoły w Bydgoszczy", No. 6, pp. 171-180.

3. Bieniek-Majka M. (2014), Integracja na rynku owoców i warzyw jako efekt członkostwa Polski w Unii Europejskiej, "Przegląd Zachodniopomorski” Issue 3, Vol.2, pp. 81-92

4. Bieniek-Majka M. (2015a), Rynek owoców i warzyw w Polsce w latach 20042014 [in:] Czyżewski A., Czakowski D. (ed.) Efektowność ekonomiczna i adekwatność społeczna w wyborach gospodarczych, Bydgoszcz, p. 28.

5. Bieniek-Majka M. (2015b), Determinanty eksportu owoców i warzyw z Polski w latach 2004-2014, "Roczniki Naukowe SERiA”, Vol. XVII, Issue 4, pp. 34.

6. Bieniek-Majka M., Matuszczak A. (2017), Rentowność kujawsko-pomorskich grup i organizacji producentów owoców i warzyw, ,Zeszyty Naukowe Szkoły Głównej Gospodarstwa Wiejskiego w Warszawie Problemy Rolnictwa Światowego" Vol. 17 (XXXII), Issue 3, pp. 7-16.

7. Czakowski D. (2017), Konkurencyjność międzynarodowa podstawowych produktów rolnych $w$ Polsce przed i po akcesji do Unii Europejskiej (1994- 
2013), „Roczniki Ekonomiczne Kujawsko-Pomorskiej Szkoły Wyższej w Bydgoszczy", pp. 161-180.

8. Czakowski D. (2016), Tendencje w kształtowaniu się cen skupu podstawowych produktów roślinnych przed i po akcesji Polski do Unii Europejskiej (19942013), „Roczniki Ekonomicze Kujawsko-Pomorskiej Szkoły Wyższej Bydgoszczy", pp. 247-260.

9. Czakowski D., Czyżewski A. (2017), Podstawowe rynki rolne w Polsce przed i po akcesji do Unii Europejskiej. Poziom i uwarunkowania rozwoju, KPSW, Bydgoszcz, p. 136-145.

10. Czyżewski A., Czakowski D. (2016), Selected economic relationships on the fruit and vegetable market in Poland (1994-2013), "Journal of Agribusiness and Rural Development", No. 4 (42), pp. 511-519.

11. Czyżewski A., Czyżewski B. (2015), Ziemia i jej renty w nowym paradygmacie rozwoju rolnictwa, [in:] Czyżewski A., Klepacki B. (ed.), Problemy rozwoju rolnictwa i gospodarki żywnościowej w pierwszej dekadzie członkostwa Polski w Unii Europejskiej, PTE, Warszawa, p. 32.

12. Filipiak T. (2014), Zmiany na rynku warzyw i w gospodarstwach warzywniczych w Polsce po integracji z Unia Europejska, SGGW, Warszawa, p. 24-26.

13. Skup i ceny produktów rolnych - data for years 2004-2016 (2005-2017) Główny Urząd Statystyczny, Warszawa.

14. Wyniki produkcji roślinnej - data for years 2004-2016 (2005-2017) Główny Urząd Statystyczny, Warszawa.

15. Rocznik statystyczny RP 2016 (2016), Główny Urząd Statystyczny, Warszawa.

16. Kapusta F. (2014), Rynek owoców w Polsce w okresie przedakcesyjnym i po akcesji do Unii Europejskiej [in:] Ekonomia XXI wieku, UE, Wrocław, pp. 9-10.

17. Nosecka B., Pawlak K., Poczta W. (2011), Wybrane aspekty konkurencyjności rolnictwa, IERiGŻ, Warszawa, p. 33-43.

18. Ziętara W., Sobierajewska J. (2012), Gospodarstwa ogrodnicze w Polsce $i$ w wybranych krajach Unii Europejskiej, IERiGŻ, Warszawa, p. 28-29.

19. Przedwynikowy szacunek głównych ziemiopłodów rolnych i ogrodniczych w 2011 r., Główny Urząd Statystyczny, http:/ / stat.gov.pl/cps/rde/xbcr/ gus/rl_przedwynik_szac_glow_ziemioplod_rol_i_ogrodniczych_2011. pdf (01.03.2018 - access date) 